\title{
POPULATION STRUCTURE OF Araucaria angustifolia IN THE IGUAÇU NATIONAL PARK
}

\author{
Alci Albiero Junior ${ }^{1}$, Lívia Godinho Temponi ${ }^{2}$, Franklin Galvão ${ }^{3}$, Paulo Cesar Botosso ${ }^{4}$, \\ Ana Tereza Bittencourt Guimarães ${ }^{2}$ \\ ${ }^{1}$ Federal University of Paraná, Post-Graduation in Bothanic Sciences, Curitiba, Paraná, Brazil - junioralbiero@ hotmail.com \\ ${ }^{2}$ State University of Western Paraná, Center of Health and Biological Sciences, Cascavel, Paraná, Brazil - \\ liviatemponi@yahoo.com.br; anatbguimarães@gmail.com \\ ${ }^{3}$ Federal University of Paraná, Department of Forest Sciences, Curitiba, Paraná, Brazil - fgalvao@ufpr.br \\ ${ }^{4}$ Brazilian Agricultural Research Corporation (Embrapa), Colombo, Paraná, Brazil - paulo.botosso@embrapa.br
}

Received for Publication: 11/03/14 - Accepted for publication: 10/11/14

\begin{abstract}
The aim of this study was to analyze the population structure, regeneration and spatial distribution of Araucaria angustifolia (Bertol.) Kuntz. within a natural forest and in forest edge with agricultural monoculture. All araucaria individuals from $10 \mathrm{~cm}$ high were recorded in 200 plots of $10 \mathrm{x} 10 \mathrm{~m} .479$ individuals were sampled (416 at the edge and 63 inside). Of these, 33 were females, 37 males, 49 juveniles and 360 regenerating individuals. The population structure performance was similar to standard inverted-J. Regenerating individuals had mainly the aggregate distribution pattern, while juveniles, males and females had a uniform pattern. Density of the canopy affected frequency of the individuals, where higher frequencies at higher densities were observed, indicating that regeneration of this species is more effective in shadowed environments. Due to the large number of individuals sampled in different size classes, the Iguaçu National Park is an important conservation remaining of A. angustifolia.

Keyword: Density canopy; mixed temperate rain forest; spatial distribution; regeneration.
\end{abstract}

\section{Resumo}

Estrutura populacional de Araucaria angustifolia no Parque Nacional do Iguaçu. O objetivo do presente trabalho foi analisar a estrutura populacional, regeneração e distribuição espacial de Araucaria angustifolia (Bertol.) Kuntz no interior de uma floresta natural e na borda de uma floresta com monocultura agrícola. Todos os indivíduos de araucária a partir de $10 \mathrm{~cm}$ de altura foram registrados em 200 parcelas de 10 × 10 m, sendo amostrados 479 indivíduos (416 na borda e 63 no interior). Desses, 33 eram fêmeas, 37 machos, 49 juvenis e 360 regenerantes. A estrutura da população apresentou padrão semelhante ao J-invertido. Os indivíduos regenerantes apresentaram principalmente o padrão agregado de distribuição, já para os juvenis, machos e fêmeas o padrão foi uniforme. A densidade do dossel influenciou a frequência de indivíduos, sendo observadas maiores frequências em maiores densidades, indicando que a regeneração da espécie é mais efetiva em ambientes sombreados. Devido ao grande número de indivíduos amostrados em diferentes classes de tamanho, o Parque Nacional do Iguaçu representa um importante remanescente na conservação de A. angustifolia.

Palavras-chave: Densidade do dossel; Floresta Ombrófila Mista; distribuição espacial; regeneração.

\section{INTRODUCTION}

The current state of depletion of the Mixed Ombrophylous Forest or Araucaria Forest (MOF) is directly related to its most characteristic species, Araucaria angustifolia (Bertol.) Kuntze, which, due to the high quality of its timber, suffered great exploitation over its history (DUARTE et al., 2002); SANQUETA et al., 2010). Reduction of MOF remains resulted in degradation of araucaria population, hindering natural regeneration (SHIMIZU et al., 2000) and taking the species to the status of "critically endangered" by the Red List of Threatened Species - IUCN (FARJON, 2012) and "endangered" in the Livro Vermelho da Flora do Brasil (Carlucci et al., 2013). Although being threatened, A. angustifolia plays a key role in the structure and working of this ecosystem, being the species with the higher economic value of the AF, serving as resource for humans and animals, favoring the resilience of this 
phytogeographical unity (DUARTE; DILLENBURG, 2000; MATTOS et al., 2007; OLIVEIRA et al., 2009).

Some authors initially suggested a pioneering behavior of araucaria, who was supposed to develop only under great light intensity (REITZ; KLEIN, 1966). Souza et al. (2008) described araucaria as a pioneer species with long life cycle, intolerant to shadowing, and depending on disturbances for its recruiting. However, some more recent works indicated its regenerative capacity with low light intensities in natural environments (PALUDO et al., 2009; VALENTE et al., 2010; EMER; FONSECA, 2011), and in controlled conditions (INOUE et al., 1979; INOUE; TORRES, 1980; DUARTE; DILLENBURG, 2000; FRANCO; DILLENBURG, 2007).

Aggregated standard distribution of regenerating individuals is normal, while for young and adults, uniform distribution is the most observed (PALUDO et al., 2009).

Even with their great social, economic and ecologic importance, araucaria's natural populations are little studied in biological terms (MANTOVANI et al., 2004), demographic (PALUDO et al., 2009), spacial (ANJOS et al., 2004), regenerative (PALUDO et al., 2009; VALENTE et al., 2010; RIOS, 2010) and in terms of light intensity influence on their growth (DUARTE; DILLENBERG, 2000; DUARTE $e t$ $a l ., 2002$ ). Furhtermore, the few studies on these aspects in different growth conditions (for example core forest or edge with monoculture) don't include the most significant remaining of the Subtropical Forest of Southern Brazil, the Iguaçu National Park (ParNa Iguaçu) (PRIMACK: RODRIGUES, 2001).

The great reduction and fragmentation of the MOF, currently restricted to conservation units (RIBEIRO et al., 2009), and the lack of knowledge on autecology of the species, create gaps in the definition of adequate techniques for its management and conservation. This way, to know how the population structure of the species behaves in different natural environments and at different distances from the edges will allow to understand how the growing fragmentation of these areas and the consequent diminution of core areas have influence on the population structure of the most important native forest species of the wood economy in Southern Brazil (SCHEEREN, 1999).

In this context, this work aims to evaluate the structure, standard distribution, and the canopy's density effect on regeneration of Araucaria angustifolia in different growth conditions (edge and core) in the Iguaçu National Park, assuming that the species has different behaviors close to the edge and in the core of the forest.

\section{MATERIAL AND METHODS}

\section{Study area}

The study area includes two phytocenoses of the Mixed Ombrophylous Forest (MOF), typical and exclusive formation of the Southern Brazil highlands, with representation of tropical and temperate floras, with dominance of Araucaria angustifolia (Bertol.) Kuntze (RODERJAN et al., 2002). The study was conducted in the Iguaçu National Park (ParNa Iguaçu), a federal conservation unit of integral protection (RYLANDS; BRANDON, 2005). ParNa Iguaçu covers 185,262.50 ha, according to the Brazilian Institute of Environment and Natural Resources (IBAMA, 1999), forming one of the main areas with native vegetation in the state of Paraná. With the exception of the Brazilian Serra do Mar, it represents, together with the São Joaquim National Park, SC, the last remaining of the original Atlantic Forest with core bigger than 50,000 ha, being the only fragment with areas $12 \mathrm{~km}$ far from the edge (RIBEIRO et al., 2009).

The Mixed Ombrophylous Forest, object of this work, is typical of the northern section of the park, fading into the Semi-Deciduous Seasonal Forest, extending along river valleys, along the northsouth direction, in embossing areas with maximum altitudes slightly more than 600m (IBAMA, 1999).

Climate of the region, according to Köppen is Cfa, sub-tropical with minimum temperatures lower than $18{ }^{\circ} \mathrm{C}$ and maximum higher than $22{ }^{\circ} \mathrm{C}$, with predominant rainfalls in summer, however without a distinct dry season, defined by the Environmental Institute of Paraná, (IAPAR, 2013).

Geological formation is volcanic, generally showing tholeiitic type basic composition and sporadically effusive acid and intermediary rocks, respectively of dacitic and andesitic type (SALAMUNI et al., 1999).

\section{Parcels and population structure}

The two sample sites of this work (Figure 1) are located in the municipalities of Santa Tereza do Oeste, PR (edge location) and Céu Azul, PR (core location), covering the northeastern and northwestern 
sections of the Iguaçu National Park. According to information from the administrators of ParNa Iguaçu, the considered areas have no historic of burnings and/or recent signals of Forest Degradation, except for the selective extraction of some forest species - like the araucaria itself - mainly in the location close to the edge, in the recent past.

In each site were installed four sample parcels. The ones in the edge location are 50 meters from the forest edge itself $\left(25^{\circ} 07^{\prime} 69.0^{\prime \prime} \mathrm{S}\right.$ and $\left.53^{\circ} 39^{\prime} 52.6^{\prime \prime O}\right)$, an area close to an agricultural monoculture, at heights varying from 580 to 600 meters, part of the Gonçalves Dias river's micro-basin.

Parcels located in the core location are 4000 meters from the forest edge $\left(25^{\circ} 08^{\prime} 08.5^{\prime \prime} \mathrm{S}\right.$ and $\left.53^{\circ} 46^{\prime} 76.8^{\prime \prime} \mathrm{O}\right)$, at heights varying from 580 to 600 meters, in the Floriano river's micro-basin.

Each parcel of $50 \times 50 \mathrm{~m}(0.25 \mathrm{ha})$ was randomly plotted, with minimum distance of $50 \mathrm{~m}$ each other. The 0.25 ha parcels were divided into 25 sub-parcels of $10 \times 10 \mathrm{~m}\left(100 \mathrm{~m}^{2}\right)$. Thus, individuals were sampled in 200 parcels of $10 \times 10 \mathrm{~m}$, covering two ha of the total sampling area, being one ha in the edge location and one ha in the core location.

All araucaria specimens $10 \mathrm{~cm}$ or higher were assessed, and the ones with Diameter at Breast Height (DBH) bigger than $4.8 \mathrm{~cm}$ were marked with aluminum plates, having their diameter and height measured. When they did not show reproductive structures they were characterized as juvenile, and adults when they presented female strobilus (female adults) and male strobilus (male adults). Male and female strobilus were observed with a binocular, as suggested by Mantovani et al. (2004).

Regenerating individuals, the ones with DBH smaller than $4.8 \mathrm{~cm}$, where divided into different height classes, according to Rios (2010)> class 1) 10 to $50 \mathrm{~cm}$; class 2) $50.1 \mathrm{~cm}$ to $1 \mathrm{~m}$; and class 3) higher than $1 \mathrm{~m}$.

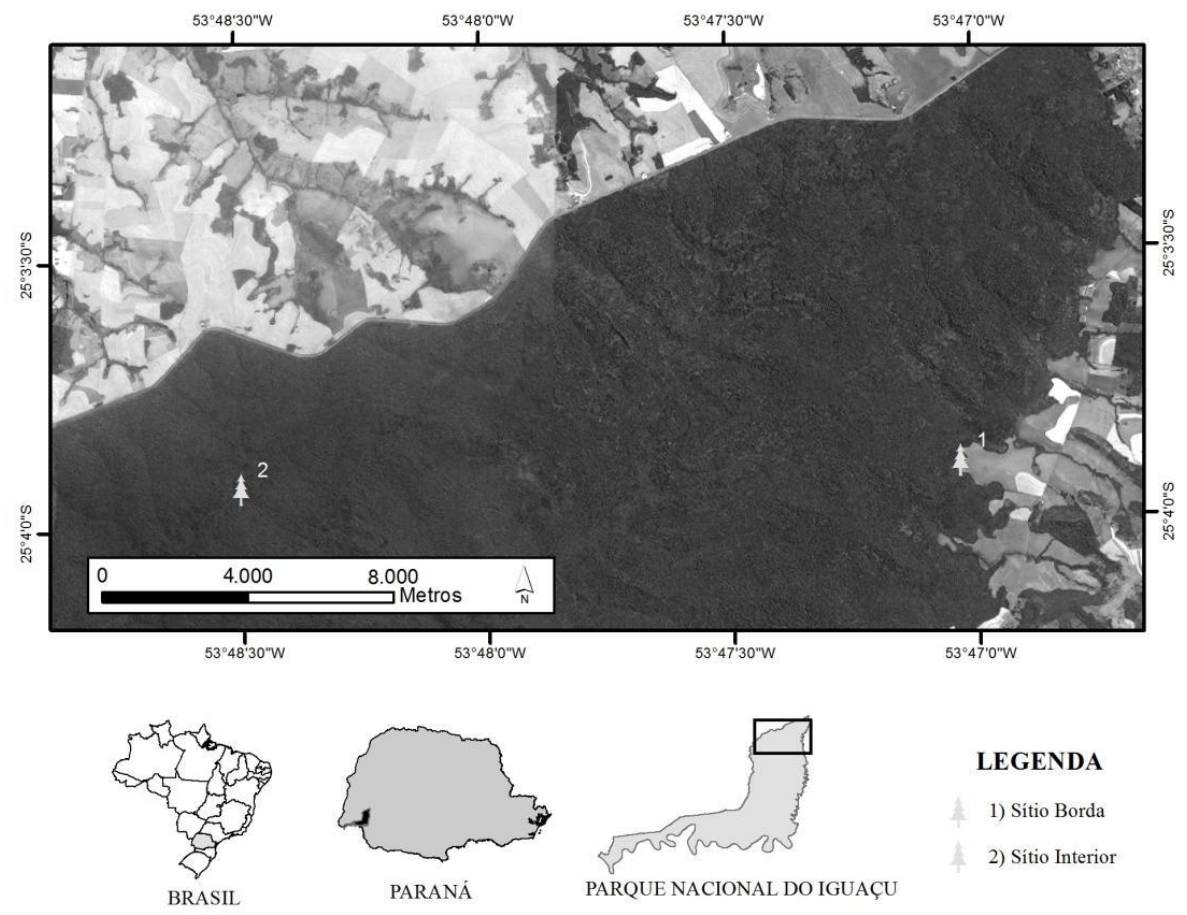

Figure 1. Paraná, Brazil, Iguaçu National Park and sites sampled.

Figura 1. Brasil, Paraná, Parque Nacional do Iguaçu e sítios amostrais.

\section{Density of forest's canopy}

Analyses of the canopy's density were performed with a Lemmon (LEMMON, 1956) convex spherical densitometer, instrument made of a convex mirror, with its center divided in 24 quadrants.

Since the instrument has curved reflecting surface, overlapping in readings originated by lateral and above head observations may reduce precision (STRICKLER, 1959). Thus, to reduce canopy observations on sides and above the head of the observer, minimizing repeated observations as indicated by Kelley and

FLORESTA, Curitiba, PR, v. 45, n. 2, p. 361 - 372, abr. / jun. 2015.

Albiero Junior, A. et al.

ISSN eletrônico 1982-4688 / ISSN impresso 0015-3826

DOI: 
Kreuger (2005), readings of densitometer were considered according to modifications suggested by Strickler (1959). This modification allows calculation of mean density values without errors induced by duplicate points and requires less time, reducing confusion to observations (STRICKLER, 1959).

The technique consists in using just 17 points of the 24 quadrants, registering the ones covered by canopy. This way, to calculate means of density of each parcel, all 17 points covered by canopy in four measurements (north, south, east, west) were summed and multiplied by 1.5 and the percentage correction of canopy's density was assumed by this number. In order to obtain greater reading precision, measurements were performed in the central part of each sub-parcel (10x10), always by the same person at 1 meter distance from the ground (PALETTO; TOSI, 2009).

\section{Structural variables and statistical analyses.}

Density of individuals was compared between areas through the Chi-squared test for homogeneity. Diametric classes between locations were assessed through the not-parametric MannWhitney-U test.

Quantitative variables diameter and height were assessed in the category of regenerating individuals, male, female and juveniles. Those data were analyzed in terms of distribution standard through the Kolmogorov-Smirnov \& Lilliefors test, and homogeneity of variances was assessed through the Levene' test. If variables did not present normality, and they did not present homoscedasticity, they were compared between areas through the Mann-Whitney-U not-parametric test. Variables were also compared between genera (male and female), within each location using the same statistical method.

Sexual proportion was assessed through the Chi-squared test to evaluate homogeneity, expecting a classic genetic proportion of 1:1.

Dependence of female frequency in regeneration was assessed using the Chi-squared test for independence.

To analyze the standard special distribution, the Index of Morisita (Id) was used, being Id=1, random distribution; Id $>1$, grouped distribution; Id $<1$, uniform distribution. In order to verify significance of the index, the Chi-squared test was used according to Krebs (1989).

Canopy' density between sites was assessed through the t-test for independent samples, since those data gave positive results in terms of normality and homoscedasticity.

Data of height and DBH were correlated with canopy's density through the Pearson's Coefficient of Correlation and their statistical significance was assessed through the t-test of correlation.

Frequencies of regenerating individuals were compared between canopy's densities classes (49 at $74 \%$ and 75 at $100 \%$ ), independently on the assessed locations, through the Mann-Whitney-U test.

Statistical tests were performed using the XLSTAT 2013 software at 5\% level of probability.

\section{RESULTS AND DISCUSSION}

In the two sampling locations were totally recorded 479 araucaria individuals, 33 females, 37 males, 49 juveniles and 360 regenerating individuals (Table 1). Density of individuals between locations was statistically significant $\left(\chi^{2}=20.04 ; p<0.05\right)$, being observed 416 individuals.ha $^{-1}$ in the edge location and 64 individuals.ha ${ }^{-1}$ in the core location.

Density of individuals in the edge (416 ind.ha ${ }^{-1)}$ may be considered high compared to the works by Paludo et al. (2009) (100 ind.ha $\left.{ }^{-1}\right)$, Mantovani et al. (2004) (32 ind.ha $\left.{ }^{-1}\right)$, Navares (2005) (23 ind.ha $\left.{ }^{-1}\right)$, and Ligner et al. (2007) (64 ind.ha $\left.{ }^{-1}\right)$. Although the sampled population in the core location had the lowest density of individuals (64 ind.ha ${ }^{-1}$ ), these results are in contradiction with Fontoura et al. (2006) who reported absence of araucarias at the distance of 250 meters from the forest edge. This low density standard was also observed by Backes (2001), Duarte et al. (2002), Navares et al. (2005), Puchalski et al. (2006) and Valente et al. (2010), who reported low density of araucaria in communities with advanced successional aging, characteristic of the core location of this work.

Despite the difference in density, it was possible to verify that the two populations presented a similar structural standard $(\mathrm{U}=372 ; \mathrm{p}=0.35)$, with tendency to inverse-J (Figure 2), characteristic of dynamic and unevenly aged populations (KOLEHMAINEN; MULTIKAINEM, 2007). However, they did not present characters of a balanced forest, because they did not show a constant reduction rate in number of plants following diameter increase (MEYER, 1952). 
Table 1. Individuals sampled at different sites in the National Park Iguaçu.

Tabela 1. Indivíduos amostrados nos diferentes sítios, no Parque Nacional do Iguaçu.

\begin{tabular}{lcccccccc}
\hline \multirow{2}{*}{ Classes } & \multicolumn{4}{c}{ Edge site } & \multicolumn{5}{c}{ Core site } \\
\cline { 2 - 9 } & DA & DR & FA & FR & DA & DR & FA & FR \\
\hline Females & 24 & 5.7 & 21 & 11.5 & 9 & 14.29 & 6 & 15.8 \\
Males & 29 & 6.9 & 25 & 13.7 & 8 & 12.7 & 7 & 18.4 \\
Juvenile & 46 & 11.07 & 26 & 14.2 & 3 & 4.76 & 3 & 7.9 \\
R1 & 179 & 43.2 & 52 & 28.4 & 14 & 22.2 & 7 & 18.4 \\
R2 & 107 & 25.7 & 42 & 23.0 & 25 & 39.6 & 12 & 31.6 \\
R3 & 31 & 7.45 & 17 & 9.3 & 4 & 6.3 & 3 & 7.9 \\
\hline Total & 416 & & & & 63 & & & \\
\hline
\end{tabular}

R1: Regenerating 1; R2: Regenerating 2; R3: Regenerating 3; DA: Absolute density; DR: Relative density; FA: Absolute frequency; FR: Relative frequency.

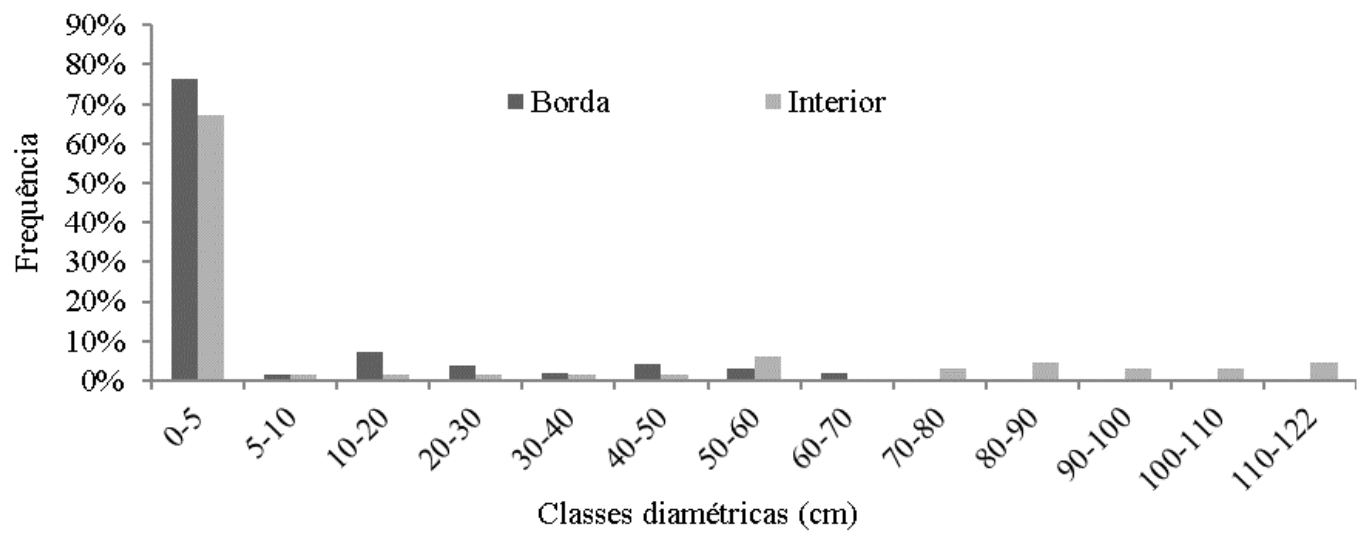

Figure 2. Frequencies of individuals by diameter classes in sample sites of the Iguaçu National Park.

Figura 2. Frequências dos indivíduos por classes diamétricas nos sítios amostrais do Parque Nacional do Iguaçu.

The reduced number of trees in the core site between classes from 60 to $70 \mathrm{~cm}$ diameter, and in the edge site starting from $70 \mathrm{~cm}$ diameter, may indicate that there have been a previous disturbance (PINHEIRO; MONTEIRO, 2009). Lack of individuals in the bigger diameter classes in the forest edge site corroborates the conservation status, being characterized as a less conserved in the intermediate stages of succession caused by proximity to the conservation area limits and possible timbering in the past (WATZLAWICK et al., 2013). In the core site, lack of individuals in the classes from 60 to $70 \mathrm{~cm}$ also suggests alteration in the population structure, as suggested by Felifili et al. (1988), where in most of the cases discontinuities, flattening and even total absence of trees are observed, in some of the diametric classes.

The structural standard found may be in relation with the physiological characteristics of araucaria, which presents the bank of seedlings as regeneration strategy, for having recalcitrant seed (DUARTE et al., 2002). Thus, the greater density of individuals in the smaller size classes would be in relation to intrinsic factors of the species.

The smaller density of individuals in the forest core site might be influenced by formation of a dense layer of herbaceous species, affecting light intensity and consequently inhibiting regeneration of the species, corroborating data from Einig et al. (1999).

However, it is known that araucaria survives in areas with moderate shadowing (INQUE et al., 1979; INQUE; TORRES, 1980; DUARTE; DILLEMBURG, 2000). Therefore, proximity to forest edge seems to favor regeneration of the species, which has seeds with great nutritive reserves and then favoring its rapid initial growth (EINIG et al., 1999; ZANDAVALLI, 2006). Another factor that might be related to low density of individuals in the lower size classes in the forest core location would be seeds collection by anthropic intervention (SOUZA, 2007). However, it is believed that this is not the case in the studied area, for it is a conservation area of total protection and the studied site presents difficult access, for these

FLORESTA, Curitiba, PR, v. 45, n. 2, p. 361 - 372, abr. / jun. 2015.

Albiero Junior, A. et al.

ISSN eletrônico 1982-4688 / ISSN impresso 0015-3826

DOI: 
reasons it is believed that seeds collection would not be convenient for population living near the ParNa Iguaçu. On the other hand, predation pressure of small rodents might have negative influence on regeneration of species in the denser canopy forests (IOB; VIEIRA, 2008; GUGLIELME; GRANADE, 2006) like the core forest site.

This way, it is believed that low density of araucaria in the most preserved areas like the one under study is a characteristic of the species and its distribution pattern would be more related to broadleaved trees systems that are in competition, and not to environmental conditioning factors (ZANDAVALLI, 2006) (e.g. light intensity). This characteristic suggests that the aging pattern of araucaria's natural forest populations might be useful in the description of the preservation status of the assessed phytocenosis. It is thus that arises the hypothesis that high densities are characteristics of less preserved areas, encountered in initial and intermediary stages of succession, and that low densities are characteristics of more preserved areas characterized by more advanced succession stages.

Correlating diameter and height of individuals it was possible to observe that males showed statistically significant differences of $\mathrm{DBH}(\mathrm{U}=22.500 ; \mathrm{p}=0.001)$ and height $(\mathrm{U}=37 ; \mathrm{p}=0.007)$ between locations, and the individuals of the core site presented greatest values for these variables. Thus, $75 \%$ of males had DBH up to $103 \mathrm{~cm}$ and height up to $25 \mathrm{~m}$, while $75 \%$ of males of the edge site had DBH up to $50 \mathrm{~cm}$ and heights up to $20 \mathrm{~m}$.

In the evaluation of females, only DBH showed significant differences $(U=54, p=0.02)$, with $75 \%$ of females in the core site had DBH up to $85 \mathrm{~cm}$ and $75 \%$ of females in the edge site had DBH up to $61 \mathrm{~cm}$. Juvenile individuals did not show significant differences between sites ( $>0.05)$.

These results corroborate with the structure of sites, where the core forest is the most preserved area, in most advanced succession stages, presenting individuals with biggest DBHs and heights.

Making correlations between genera in the edge sites it was possible to verify statistically significant differences in the values of DBH between males and females $(U=206,500 ; p=0.01)$, where $75 \%$ of females presented DBH up to $60 \mathrm{~cm}$ and $75 \%$ of edge site males had DBH up to $50 \mathrm{~cm}$. Initially, this result was not expected, because araucaria is a dioecious species and females should have more energy consumption, reducing their growth rate. However, this relation was not observed in this study, neither by Paludo et al. (2009), where the biggest diameter of female individuals was attributed with previous timbering of the area with selective strategy, before it turned into a preservation area. There was no statistically significant between DBH and height in genera of the core site $(\mathrm{p}=0.05)$.

The expected sexual proportion (1:1) in the two sampling sites was statistically proved, both in the edge $\left(\chi^{2}=0.236 ; p=0.627\right)$ and in the core sites $\left(\chi^{2}=0.029 ; p=0.864\right)$.

It was possible to observe independence of females in regeneration $\left(\chi^{2}=41.72 ; p<0.05\right)$, result also found by Paludo et al. (2009) and Souza et al. (2008). This independence of regenerating individuals in relation to the mother plant is supported by the "Escape hypothesis" theory, given by Janzen (1971) an Connell (1971), considering mortality of seeds and seedlings as strongly dependent on density. This fact was observed in this study, since there was no observed great number of regenerating individuals close to female plants. This distance also may be in relation with the great number of vertebrates, mainly rodents and big size birds, actuating simultaneously as spreaders and predators of seeds (VIEIRA; IOB, 2006).

Spatial distribution of araucaria in both sites (Table 2) was mainly aggregate, similar to works by Nascimento et al. (2001); Paludo et al. (2009); Valente et al. (2010), possibly reflecting the high population density mainly in the edge site. According to Cottam et al. (1953) and Pielou (1960), populations with aggregate spatial distribution standard have individuals occurrence in agglomerates, thus the chance of occurrence of one individual increases with the presence of another one. In Podocarpus nagi (Thunb.) Kuntze, aggregation of regenerating individuals may be explained by the low dispersion capacity of its seeds (NANAMI et al., 1999), characteristic that probably has influence on the aggregate standard of araucaria individuals, for having heavy seeds with gravity dispersion mechanism (PALUDO et al., 2009).

However, male individuals of the core site, young and regenerating individuals, belonging to class 3 , showed uniform distribution pattern, just like males and females of the edge site. This way, the possibility of finding another individual is not conditioned to localization of the first one (KREBS, 1989).

Distribution of adult individuals does not necessarily reflect the same pattern of regenerating individuals, because their distribution reflects the recruitment spatial standard and is also influenced by mortality factors (CRAWEY, 2005). On the other hand, it is believed that difference in distribution 
pattern of regenerating class 3 between sites is influenced by difference in density of individuals (four individuals in the core site and 31 in the edge), and by mortality of regenerating individuals, which is probably bigger in the core site as result of predation (IOB; VIEIRA, 2008).

Table 2. Spatial pattern of individuals in the sample sites of the Iguaçu National Park.

Tabela 2. Padrão espacial dos indivíduos nos sítios amostrais do Parque Nacional do Iguaçu.

\begin{tabular}{lclcc}
\hline Classes & \multicolumn{1}{c}{ Core site } & \multicolumn{2}{c}{ Edge site } \\
\hline Females & $\mathrm{Id}=1.39 ; \chi^{2}=0.2$ & Uniform & $\mathrm{Id}=10 ; \chi^{2}=9.5$ & Aggregate \\
Males & $\mathrm{Id}=0.95 ; \chi^{2}=0.51$ & Uniform & $\mathrm{Id}=1.58 ; \chi^{2}=0.36$ & Uniform \\
Young & $\mathrm{Id}=3.49 ; \chi^{2}=3.8$ & Aggregate & $\mathrm{Id}=0 ; \chi^{2}=0.53$ & Uniform \\
R1 & $\mathrm{Id}=2.36 ; \chi^{2}=1.68$ & Aggregate & $\mathrm{Id}=9.23 ; \chi^{2}=1.66$ & Aggregate \\
$\mathrm{R} 2$ & $\mathrm{Id}=2.69 ; \chi^{2}=6.15$ & Aggregate & $\mathrm{Id}=9.93 ; \chi^{2}=4.15$ & Aggregate \\
R3 & $\mathrm{Id}=6.45 ; \chi^{2}=8.95$ & Aggregate & $\mathrm{Id}=13.33 ; \chi^{2}=0.008$ & Uniform \\
\hline
\end{tabular}

R1: Regenerating 1; R2: Regenerating 2; R3: Regenerating 3; Id: Morisita index; $\chi^{2}$ : Chi-squared value.

In species with high mortality rate depending on density, adult individuals tend to present less aggregate distribution than seedlings (CRWLEY, 2005). This characteristic was observed in this study, where mature individuals mainly presented uniform distribution pattern, both in the core and the edge sites.

Anjos et al. (2004) obtained different results, where more preserved and less exploited areas showed random and aggregate distribution. In preserved areas, but with uncontrolled seed harvesting by humans, distribution pattern was regular and aggregate. Souza et al. (2008) also met different results, where, in preserved sites, distribution pattern of females was random. Those differences reflect different population structure and conservation status of the analyzed sites, being aggregate and uniform pattern the normally observed araucaria distribution standard.

Initially, all classes of regenerating individuals were grouped in a single category, and compared between sites. Just diameters showed statistical significance $(\mathrm{U}=3704, \mathrm{p}=0.0001)$, while height values were statistically equivalent ( $>0.05$ ). Regenerating individuals in the core site showed bigger diameters, with $75 \%$ of diameter values up to $0.95 \mathrm{~cm}$, while in the edge site, for $75 \%$ of individuals, diameter was up to $0.63 \mathrm{~cm}$.

Separating classes of regenerating individuals allowed to verify that diameter of regenerating individuals 1 (R1) presented significant difference between sites $(\mathrm{U}=716.500 ; \mathrm{p}=0.007)$, with $75 \%$ of $\mathrm{R} 1$ of the core site had diameters up to $0.63 \mathrm{~cm}$. In the edge site representatives of R1 had smaller values, $75 \%$ of seedlings with diameter up to $0.47 \mathrm{~cm}$. Height values were considered equivalent between sites ( $>0.05$ ). Regenerating individuals class 2 (R2) also showed similar pattern to R1, with just diameter presenting statistical difference $(\mathrm{U}=716.500 ; \mathrm{p}=0.001)$. Individuals of the core site had bigger diameter values, $75 \%$ of them with diameter up to $0.95 \mathrm{~cm}$, and between individuals of the edge, $75 \%$ up to 0.70 $\mathrm{cm}$. However, this pattern was not observed in regenerating individuals class 3 (R3), where only height presented significant difference between sites $(\mathrm{U}=24, \mathrm{p}=0.04)$. Thus, class $\mathrm{R} 3$ of the internal site presented lower height values with $75 \%$ of individuals up to $123 \mathrm{~cm}$, while in the edge site $75 \%$ of individuals had height up to $194 \mathrm{~cm}$.

This result is different from what found by Inoue and Torres (1980), performing and experiment in greenhouse, where they obtained results showing increased height development depending on increased shadowing. However, Franco and Dillenburg (2007) relate that this increased height investment in shadowed plants is temporary, and this might be the case of this work.

Therefore, it is believed that, in the most preserved areas inside the forest, regenerating araucaria individuals are investing more in diametric growth than individuals of the edge site. This characteristic might be in relation with the greater density of individuals in the edge site, which are so close each other to hinder their diametric growth. According to Zanine and Ganade (2005).competition for nutrients in soil between close individuals may influence araucarias' growth, corroborating with the smaller diameter growth in denser areas.

Canopy's density between sites did not show statistical differences $(t=130 ; p>0.05)$, neither relation between diameter and height of regenerating individuals and density of canopy $(r=0.21 ; p>0.05)$. Thus, values found in different densities of canopy are believed to be independent. However, frequency of regenerating individuals presented significant differences $(U=2237,500 ; p=0.02)$, and environments 
with greater canopy's density had greater frequencies. In parcels with canopy's density varying from 49 to $74 \%$, absence of regenerating individuals was observed in $75 \%$ of parcels. In parcels with canopy's density from 75 to $100 \%$, there were up to 3 regenerating individuals in $75 \%$ of these parcels.

Table 3. Height $(\mathrm{cm})$ and diameter $(\mathrm{cm})$ of regenerating per sample site of the Iguaçu National Park.

Tabela 3. Altura $(\mathrm{cm})$ e diâmetro $(\mathrm{cm})$ dos regenerantes por sítio amostral do Parque Nacional do Iguaçu.

\begin{tabular}{|c|c|c|c|c|c|c|c|c|c|c|}
\hline \multirow{2}{*}{$\begin{array}{l}\text { Regenerating } \\
\text { classes }\end{array}$} & \multicolumn{5}{|c|}{ Edge site } & \multicolumn{5}{|c|}{ Core site } \\
\hline & $\mathbf{N}^{\circ}$ ind. & Min & $\mathbf{A v}$ & $\sigma$ & Max & $\mathbf{N}^{\circ}$ ind. & Min & Av & $\sigma$ & Max \\
\hline \multicolumn{11}{|c|}{ Altura } \\
\hline R1 & 179 & 10 & 39 & 0.24 & 50 & 14 & 13 & 35 & 0.29 & 50 \\
\hline $\mathrm{R} 2$ & 107 & 50 & 60 & 0.19 & 96 & 24 & 50 & 62 & 0.18 & 97 \\
\hline R3 & 31 & 100 & 152 & 1.22 & 500 & 4 & 100 & 112 & 0.60 & 125 \\
\hline \multicolumn{11}{|c|}{ Diameter } \\
\hline R1 & 179 & 0.15 & 0.31 & 0.37 & 1.01 & 14 & 0.15 & 0.55 & 1.39 & 4.77 \\
\hline R2 & 107 & 0.31 & 0.63 & 0.25 & 1.11 & 25 & 0.47 & 0.79 & 0.24 & 1.27 \\
\hline R3 & 31 & 0.63 & 1.27 & 0.53 & 4.14 & 4 & 0.79 & 1.11 & 0.22 & 1.27 \\
\hline
\end{tabular}

R1 (Regenerating 1); R2 (Regenerating 2); R3 (Regenerating 3); $N^{\circ}$ ind. (number of individuals); Min (minimum); Av (average); $\sigma$ (standard deviation); Max (maximum).

Putting in relation frequency of regenerating individuals and density of canopy between sites, not a single regenerating individual was identified in the core site when canopy's density was from 49 to $74 \%$. Thus, all individuals identified in the core site were found in parcels with the greatest canopy's densities values (75 to $100 \%)$.

Regenerating individuals found in the edge site were distributed in different densities of the canopy, 47 individuals (14\%) were found in densities varying from 49 to $74 \%$ and 270 individuals (86\%) were observed between 75 and 100\% canopy's density.

Therefore, canopy's density seems to have more influence on density of individuals than on their diameter and height growth patterns.

Thus, it is possible to verify that frequency of regenerating individuals was bigger in the higher canopy's densities, supporting plasticity of araucaria's growth in more shadowed environments (INOQUE et al., 1979; DUARTE; DILLENBURG, 2000; FRANCO; DILLENBURG, 2007; DUARTE et al., 2002). This result gives strength to the idea that araucaria, in its juvenile stage, is a species tolerant to shadowing, not corroborating its classification as pioneer species, intolerant to shadowing.

\section{CONCLUSION}

- Iguaçu National Park represents an important remaining for preservation of araucaria's natural population, due to the high density of sampled individuals in different size classes. Despite the significant difference in density between sites, populations analyzed present similar structural patterns, with tendency to inverse-J. It is believed that the smaller density in the internal site is a characteristic of the species, where in more preserved areas with advanced successional stages, greater competition and predation pressure are the main causes of this result.

- Light intensity verified by means of canopy's density did not represent a restrictive factor to regeneration of the species, since the greatest density of regenerating individuals was verified in shadowed sites with denser canopies. Therefore, regeneration of the species in shadowed sites is proved, not corroborating classification of araucaria as a pioneer species.

- Distribution of regenerating individuals was mainly aggregate, and adults had uniform distribution. Due to less competition as consequence of lower densities, regenerating individuals of the core site had bigger diameter values. Thereby, importance of structure in araucaria forest populations is highlighted as indicative of the preservation conditions of the assessed phytocenosys. More preserved areas presented populations with lower density, while perturbed areas, in initial and intermediate succession stages, presented greater densities of individuals of this species. 


\section{ACKNOWLEDGEMENTS}

To the Support Program for the Restructuring and Expansion of Federal Universities (REUNI), for the scholarship awarded to the first author. To all who cooperated in the field excursions, in special to the State University of Western Parana for the help in logistics ad to Assis Roberto Escher for the valuable cooperation on field.

\section{REFERENCES}

ANJOS, A.; MAZZA, M. C. M.; SANTOS, A. C. M. C.; DELFINI, L. T. Análise do padrão de distribuição espacial da araucária (Araucaria angustifolia) em algumas áreas no Estado do Paraná, utilizando a função K de Ripley. Scientia Forestalis, Piracicaba, v. 66, n. 50, p. 38 - 45, 2004.

BACKES, A. Determinação da idade e regeneração natural de uma população de Araucaria angustifolia (Bertol.) Kuntz em um povoamento florestal localizado no município de Caxias do Sul, RS, Brasil. Série Botânica Iheringia, Porto Alegre, v. 56, n. 2, p. 115 - 130, 2001.

CARLUCCI, M. B.; PRIETO, P. V.; HERING, R. L. O. JUDICE, D. M.; MONTEIRO, N. P. Araucariaceae. In: MARTINELLI, G.; MORAES, M. A. Livro vermelho da flora do Brasil. Rio de Janeiro, 2013. p. 185 - 186. Disponível em: <http://cncflora.jbrj.gov.br/LivroVermelho.pdf/>. Acesso em: $15 / 12 / 2013$.

CONNEL, J. H. On the role of natural enemies in preventing competitive exclusion in some marine animals and in rain Forest trees. In: Den Böer, P. J.; GRADWELL, G. R. Dynamics of Populations. Wagenigen, 1971.

COTTAM, G.; CURTIS, J. T.; HALE, B. W.Some sampling characteristics of a population of randomly dispersed individuals. Ecology, New York, v. 34, n. 4, p. 741 - 757, 1953.

CRAWLEY, M. J. Plant ecology. Blackwell Scientific Publications, Oxford, 2005.2ed. 717 p.

DUARTE, L. S.; DILLENBURG, L. R. Ecophysiological responses of Araucaria angustifolia (Araucariaceae) seedlings to different irradiance levels. Australian Journal of Botany, Collingwood, v. 48, n. 4, p. 531 - 537, 2000.

DUARTE, L. S.; DILLENBURG, L. R.; ROSA, L. M. G. Assessing the role of light availability in the regeneration of Araucaria angustifolia (Araucariaceae). Australian Journal of Botany, Collingwood, v. 50, n. 6, p. $741-751,2002$.

EINIG, W.; MERTZ, A.; HAMPP, R. Growth rate, photosynthetic activity, and leaf development of Brazil pine seedlings (Araucaria angustifolia [Bert.] O. Ktze.). Plant Ecology, Oxford, v. 143, n. 1, p. 23 - 28, 1999.

EMER, C.; FONSECA, C. R. Araucaria Forest conservation: mechanisms providing resistance to invasion by exotic timber trees. Biological Invasions, Knoxville, v. 13, p. 189 - 202, 2011.

FARJON, A. Araucaria angustifolia. In: IUCN 2007. 2007 IUCN Red List of Threatened Species .Disponívelem: <http://www.iucnredlist.org>. Acesso em: 05/10/2012.

FRANCO, A. M. S.; DILLENBURG, L. R. Ajustes morfológicos e fisiológicos em plantas jovens de Araucaria angustifolia (Bertol.)Kuntze em resposta ao sombreamento. Hoehnea, Porto Alegre, v. 34, n. 2, p. 135 - 144, 2007.

FONTOURA, S. M.; GANADE, G.; LAROCCA, J. Changes in plant community diversity and composition across an edge between Araucaria forest and pasture in South Brazil. Revista Brasileira de Botânica v. 29, n. 1, p. 79 - 91, 2006.

FELFILI, J. M.; SILVA JUNIOR, M. C. Distribuição dos diâmetros numa faixa de cerrado na Fazendo Água Limpa (FAL) em Brasília-DF. Acta Botanica Brasilica, São Paulo, v. 104, n. 2, p. 85 - 104, 1988.

GUGLIELME, I.; GRANADE, G. Predação de sementes afetando a distribuição de indivíduos de 
Araucaria angustifolia ao longo de uma borda de floresta com campo. Neotropical Biology and Conservation, v. 1, n. 2, n. 1, p. 62 - 71, 2006.

INSTITUTO AMBIENTAL DO PARANÁ (IAPAR). Cartas climáticas do Paraná. Disponível em: <http://www.iapar.br/modules/conteudo/conteudo.php?conteudo=597>. Acesso em: 20/12/13.

INSTITUTO BRASILEIRO DO MEIO AMBIENTE E DOS RECURSOS RENOVÁVEIS (IBAMA). Plano de manejo do Parque Nacional do Iguaçu. Foz do Iguaçu, PR, 1999.

INOUE, M. T.; GALVAO, F.; TORRES, D. V. Estudo ecofisiológico sobre Araucaria angustifolia (Bert.) O. Ktze.: Fotossíntese em dependência à luz no estágio juvenil. Revista Floresta, Curitiba, v. 10, n. 1, p. 5 - 9, 1979.

INOUE, M. T.; TORRES, D. V. Comportamento do crescimento de mudas de Arauacaria angustifolia (Bert.) O. Kuntze. em dependência da intensidade luminosa. Revista Floresta, Curitiba, v. 11, n. 1, p. 7 $10,1980$.

IOB, G.; VIEIRA, E. M. Seed predation of Araucaria angustifolia (Araucariaceae) in the Brazilian Araucaria Forest: influence of deposition site and comparative role of small and 'large' mammals. Plant Ecology, Oxford, v. 198, n. 2, p. 185 - 196, 2008.

JANZEN, D.H. Herbivores and the number of tree species in tropical forests. American Naturalist, 1970. 104: p. 501 - 528.

KELLEY, C. E.; KRUEGER, W. Canopy cover and shade determinations in riparian zones. Journal of the American water resource association, Middleburg, v. 41, n. 1, p. 37 - 46, 2005.

KOLEHMAINEN, J.; MUTIKAINEN. Population stage structure, survival and recruitment in the endangered East African forest herb Saint Paulia. Plant Ecology, Oxford, v. 192, n. 1, p. 85 - 95, 2007.

KREBS, C. J. Ecological methodology.New York, Harper and Hall, 1989.654 p.

LEMMON, P. E. A spherical densiometer for estimating forest overstory density. Forestry Sciences, Bethesda, v. 2, p. 314 - 320, 1956.

LINGNER, D. V.; OLIVEIRA, Y. M. M.; ROSOT, N. C.; DLUGOSZ, F. F. Caracterização da estrutura e da dinâmica de um remanescente de floresta com araucária no planalto catarinense. Pesquisa Florestal Brasileira, Colombo, n. 55, p. 55 - 66, 2007.

MANTOVANI, A.; MORELLATO, L. P. C.; REIS, M. S. Fenologia reprodutiva e produção de sementes em Araucaria angustifólia (Bert.) O. Ktze. Revista Brasileira de Botânica, São Paulo, v. 27, n. 4, p. 787 - 796, 2004.

MATTOS, P. P.; SANTOS, A. T.; OLIVEIRA, Y. M. M.; ROSOT, M. A. D. Dendrocronologia de espécies da floresta ombrófila mista do município de Candói, Pr. Colombo: Embrapa Florestas, 2007.

MEYER, H. A. Structure, growth, and drain in balanced uneven-aged forests.Journal of Forestry, Washington, v. 50, n. 2, p. 85 - 95, 1952.

NANAMI, S.; KAWAGUCHI, H.; YAMAKURA, T. Dioecy-induced spatial patterns of two codominant tree species, Podocarpus nagi and Neolitsea aciculata. Journal of Ecology. v. 87, p. 678 - 687, 1999.

NAVARES, I. S.; BRENA, D. A.; LONGHI, S. J. Estrutura da regeneração natural em floresta ombrófila mista na Floresta Nacional de São Francisco de Paula RS. Ciência Florestal, Santa Maria, v. 15, n. 4, p. $331-342,2005$.

NASCIMENTO, A. R. T.; LONGHI, S. J.; BRENA, D. A. Estrutura e padrão de distribuição espacial de espécies arbóreas em uma amostra de floresta ombrófila mista em Nova Prata, RS. Ciência Florestal, Santa Maria, v. 11, n. 1, p. 105 - 119, 2001.

OLIVEIRA, J. M.; SANTAROSA, E.; PILLAR, V. D.; ROIG, F. A. Seasonal cambium activity in the subtropical rain forest tree Araucaria angustifolia. Trees, Berlin,v. 23, p. 107 - 115, 2009.

PALETTO, A.; TOSI, V. Forest canopy cover and canopy closure: comparison of assessment techniques. 
European Journal of Forest Research, v. 128, n. 3, p. 265 - 272, 2009.

PALUDO, G. F.; MANTOVANI, A.; KLAUBERG, C.; REIS, M. S. Estrutura demográfica e padrão espacial de uma população natural de Araucaria angustifolia (Bertol.) Kuntze (Araucariaceae), na reserva genética florestal de Caçador, estado de Santa Catarina. Revista Árvore, Viçosa, v. 33, n. 6, p. 1109 1121, 2009.

PINHEIRO, M. H. O.; MONTEIRO, R. Análise estrutural e considerações sobre a dinâmica sucessional de dois fragmentos florestais semideciduais do Jardim Botânico Municipal de Bauru, SP, Brasil. Acta Botanica Brasilica, São Paulo,v. 23, n. 4, p. 968 - 975, 2009.

PIELOU, E. C. A single mechanism to account for regular, random and aggregated populations. Journal of Ecology. v. 48, n. 3, p. 575 - 584, 1960.

PRIMACK, R. B.; RODRIGUES, E. Biologia da conservação. Londrina: E. Rodrigues, 2001. 328 p.

PUCHALSKI, A.; MANTOVANI, M. Variação em populações naturais de Araucaria angustifolia (Bert.) O. Kuntze associada a condições edafo-climáticas. Scientia Forestalis, Piracicaba, n. 70, p. 137 - 148, 2006.

REITZ, R.; KLEIN, R. Araucariáceas. In: REITZ, R. (Ed.). Flora Ilustrada Catarinense. Itajaí: Herbário Barbosa Rodrigues, 1966. 65 p.

RIBEIRO, M. C.; METZGER, J. P.; MARTENSEN, A. C.; PONZONI, F. J.; HIROTA, M. M. The Brazilian Atlantic Forest: How much is left, and how is the remaining Forest distributed? Implications for conservation. Biological Conservation.New York, v. 142, n. 6, p. 1141 - 1153, 2009.

RIOS, C. M. Capacidade regenerativa da floresta missioneira argentina frente a distúrbios antrópicos. $172 \mathrm{f}$. Tese (Doutor em engenharia florestal-Conservação da natureza) - Universidade Federal do Paraná, Curitiba, 2010.

RODERJAN, C. V.; GALVÃO, F.; KUNIYOSHI, Y. S.; HATSCHBACK, G. As unidades fitogeográficas do Estado do Paraná. Ciência \& Ambiente, Santa Maria, v. 24, p. 75 - 92, 2002.

RYLANDS, A. B.; BRANDON, K. Unidades de conservação brasileiras. Megadiversidade, Belo Horizonte, v. 1, n. 1, p. 27 - 35, 2005.

SALAMUNI, R.; ROCHA, L. A.; ROCHA, A.L.;SALAMUNI, E. 1999. O Parque Nacional do Iguaçu. In: SCHOBBENHAUS,C.; CAMPOS,D.A.; QUEIROZ,E.T.; WINGE,M.; BERBERT, B. M. (Edit.) Sítio Geológicos e Paleontológicos do Brasil. Disponível em:<www.unb.br/ig/sigep/sitio011.htm/>. Acesso em 03/10/2011.

SANQUETA, C. R.; THIELE, P.; CORTE, A. P. D. Crescimento, mortalidade e recrutamento de duas florestas de araucária no estado do Paraná, Brasil, no período de 1995-2007. Naturalia, Rio Claro, v. 33, p. 117 - 126, 2010.

SCHEEREN, L. W.; FINGER, C. A. G.; SCHUMACHER, M. V.; LONGHI, S. J. Crescimento em altura de Araucaria angustifolia (Bert.) O. Ktze. em três sítios naturais, na região de Canela - RS. Ciência Florestal, Santa Maria, v. 9, n. 2, p. 23 - 40, 1999.

SHIMIZU, J. Y.; JAEGER, P.; SOPCHAK, S. A. Variabilidade genética em uma população remanescente de araucária no Parque Nacional do Iguaçu, Brasil. Pesquisa Florestal, Colombo, n. 41, p. 18 - 36, 2000.

SOUZA, A. F. Ecological interpretation of multiple population size structures in trees: The case of Araucaria angustifolia in South America. Austral Ecology, v. 32, p. 524 - 533, 2007.

SOUZA, A. F.; FORGIARINIB, C.; LONGHI, S. J.; BRENAC, D. A. Regeneration patterns of a longlived dominat conifer and the effects of logging in southern South America. Acta Oecologica, Montrouge, v. 34, n. 1, p. 221 - 232, 2008.

STRICKLER, G. S. Use of the Densiometer to Estimate Density of Forest Canopy on Permanent Sample

FLORESTA, Curitiba, PR, v. 45, n. 2, p. 361 - 372, abr. / jun. 2015.

Albiero Junior, A. et al.

ISSN eletrônico 1982-4688 / ISSN impresso 0015-3826

371

DOI: 
Plots. USDA Forest Service, Washington, v. 180, p. 5, 1959.

VALENTE, T. P.; NEGRELLE, R. B.; SANQUETA, C. R. Regeneração de Araucaria angustifolia em três fitofisionomias de um fragmento de floresta ombrófila mista. Iheringia.Porto Alegre, v. 65, n. 1, p. $17-24,2010$.

WATZLAWICK, L. F.; GARDIN, E.; LONGHI, S. J.; ANDRADE, E. C. L. Estimate of the diameter distribution in mixed ombrophylous florest fragment with the Meyr's function. Applied Research e Agrotecnology, Guarapuava, v. 6, n. 1, p. 29 - 36, 2013.

ZANDAVALLI, R. B. Importância da competição durante o estabelecimento e crescimento inicial da Araucaria angustifolia. 167 f. Tese (Doutor em Botânica) - Universidade Federal do Rio Grande do Sul, Porto Alegre, 2006.

ZANINE, L.; GANADE, G. Restoration of Araucaria forest: the role of perches, pioneer vegetation, and soil fertility. Restoration Ecology, v. 13, n. 3, p. 507 - 514, 2005. 